\title{
PENURUNAN TINGKAT KECEMASAN DAN GULA DARAH PADA PENDERITA DM TIPE 2 MELALUI SPIRITUAL MINDFULNESS BASED ON BENSON RELAXATION
}

\author{
Riska Rohmawati*, Arif Helmi \\ Fakultas Keperawatan dan Kebidanan, Universitas Nahdlatul Ulama Surabaya, Jl. Raya Jemursari No.57, Jemur \\ Wonosari, Kec. Wonocolo, Kota SBY, Jawa Timur, Indonesia 60237 \\ *riskarohmawati@unusa.ac.id
}

\begin{abstract}
ABSTRAK
Perubahan mendadak dalam hidup membuat penderita DM menunjukkan beberapa reaksi psikologis negatif yang menghasilkan glukosa darah. Tujuan dari penelitian ini adalah untuk menjelaskan pengaruh mindfulness spiritual berdasarkan relaksasi benson pada kecemasan, gula darah pada pasien DM tipe 2 . Penelitian ini menggunakan desain penelitian eksperimental quasy dengan pre-test dan post-test dengan desain kelompok kontrol dengan sampel 30 responden dan teknik pengambilan sampel menggunakan consecutive sampling. Intervensi dilakukan selama 4 minggu (15 menit untuk setiap intervensi). Penelitian ini menggunakan instrumen kuesioner SRAS Zung untuk kecemasan dan glukometer untuk mengukur GDP dan GDPP. Tes statistik menggunakan Mann Whitney Test dan Wilcoxon Signed. Hasil tes statistik menunjukkan bahwa perhatian spiritual berdasarkan relaksasi benson mempengaruhi penurunan kecemasan pada setiap kelompok ( $\mathrm{p}=0,000$ untuk kelompok perlakuan dan $\mathrm{p}=1,00$ untuk kelompok kontrol), secara signifikan mengurangi kadar glukosa darah rata-rata $(\mathrm{p}=0,000$ untuk perawatan kelompok dan $\mathrm{p}=0,48$ untuk kelompok kontrol). Perhatian spiritual berdasarkan benson relaksasi membantu pasien meningkatkan fokus mereka pada kondisi saat ini tanpa upaya untuk menyalahkan diri sendiri, orang lain, dan lingkungan sehingga pasien lebih nyaman dan merasa tenang. Intervensi ini mempengaruhi pengurangan kecemasan, rata-rata gula darah pasien DM tipe 2 .
\end{abstract}

Kata kunci: DM tipe 2, gula darah, kecemasan, perhatian spiritual, reaksasi benson

\section{REDUCING ANXIETY AND BLOOD SUGAR LEVELS ON DM TYPE 2 PATIENTS THROUGH SPIRITUAL MINDFULNESS BASED ON BENSON RELAXATION}

\begin{abstract}
Sudden changes in life make DM sufferers show some negative psychological reactions that result in a blood glucose. The purpose of this study was to explain the influence of spiritual mindfulness based on benson relaxation on anxiety, blood sugar in DM type 2 patients. This study used a quasy experimental study design with pre-test and post-test with control group design with a sample of 30 respondents and a sampling technique using consecutive sampling. The intervention was carried out for 4 weeks (15 minutes for each intervention). This study uses the Zung SRAS questionnaire instrument for anxiety and a glucometer to measure GDP and GDPP. Statistical tests using the Mann Whitney Test and Wilcoxon Signed. Statistical test results show that spiritual mindfulness based on benson relaxation affects the decrease in anxiety in each group ( $p=0.000$ for the treatment group and $p=1.00$ for the control group), significantly reducing average blood glucose levels ( $p=0.000$ for the treatment group and $p=0,48$ for the control group). Spiritual mindfulness based on benson relaxation helps patients improve their focus on current conditions without any effort to blame themselves, others, and the environment so that patients are more comfortable and feel calm. This intervention affected the reduction of anxiety, average blood sugar of type 2 DM patients.
\end{abstract}

Keywords: anxiety, benson relaxation, blood sugar, spiritual mindfulness, type 2 DM

\section{PENDAHULUAN}

Diabetes Mellitus (DM) termasuk salah satu penyakit degeneratif yang tidak menular yang akan meningkat jumlahnya di masa yang akan datang. WHO memperkiakan bahwa kenaikan jumlah penyandang DM di Indonesia dari 8,4 juta pada tahun 2000 menjadi sekitar 21,3 juta pada tahun 2030. Laporan ini menunjukkan adanya peningkatan jumlah penyandang DM sebanyak 2 - 3 kali lipat pada tahun 2035. (Perkeni, 2015).

Penderita DM sering mengalami banyak baik secara fisiologis maupun secara psikologis. Seseorang yang terdiagnosa DM akan menunjukan beberapa reaksi psikologis, seperti 
marah, mrasa tidak berguna, kecemasan akan prognosis penyakitnya hingga ada yang mengalami depresi Seseorang dengan penyakit kronis, rentan mengalami kecemasan. Terdapat 48\% pendeita DM mengalami kecemasan, sedangkan badan kesehatan dunia melaporkan sekitar $27 \%$ pasien DM mengalami kecemasan akan penyakitnya. (David, 2004; Hsanat, 2010).

Stres yang berkepanjangan akan menjadikan seseorang mengalami kecemasan. Kecemsan penderita DM akan berdampak pada peningkatan produksi epinefrin, metabolisme glukosa, asam lemak, dan sam nukleat yang dapat membuat seseorang sering merasa lapar (Thomas, 2003). Pada keadaan cemas aktivitass aksis HPA akan meningkat dan menyebabkan peningkatan kadar kortisol yang mempengaruhi fungsi insulin baik dalam hal sensitivitas, produksi, dan reseptor sehinggga kdar gula darah tidak bisa diseimbangkan (Putra, 2011)

Salah satu bentuk intervensi nonfarmakologis dalam menurunkan tingkat kecemasan adalah latihan mindfulness. Mindfulness merupakan suatu latihan penerimaan diri terhadap apa yang terjadi sekarang, dan membangun kesadaran diri. West (2008) menyatakan bahwa latihan mindfulness menjadikan seseorang memiliki hidup yang lebih sehat dan tidak mudah cemas, tidak mudah depresi, dan fungsi imunitas tubuh lebih meningkat.

Aspek spiritual merupakan salah satu aspek yang dapat memperbaiki persepsi individu terhadap dirinya. Seseorang dapat beradaptasi dengan perubahan akibat penyakit kronis dengan pendekatan spiritual. Spiritual dapat dijadikan pendamping terapi konvensional jika dilakukan dengan teratur karena menumbuhkan sistem koping yang positif yang akhirnya cemas atau stres dapat dihilangkan.

Peneltian yang dilakukan Brantley dan Millstine (2011) menyebutkan responden dalam program pengurangan stres yang berdasarkan kesadaran (MBSR) dikaitkan dengan peningkatan kesadaran dan spiritualitas, dan untuk meneliti hubungan antara kesadaran, spiritualitas, dan gejala medis dan psikologis. Hasil penelitian menunjukkan bahwa terjadi perubahan signifikan pada spiritualitas, tekanan psikologis dan laporan gejala medis pada responden yang diberikan terapi MBSR selama 7 minggu dengan 2,5 jam/minggu. Hal tersebut sekalan dengan penelitian yang dulakukan Tuty Alawiyah
(2018) yang menyebutkan intervensi spiritual mindfulnes based breathing relaxation 3 kali sehari selama sebulan dapat menurunkan tingkat stress, kadar gula dan tekanan darah. Sedangkan Rosenszweig (2007) menyatakan perubahan kontrol glikemik, berat badan, tekanan darah, dan gejala psikologis - stres pada pasien DM tipe 1 dengan memberikan intervensi MBSR yang dilaksanakan selama 4 minggu. Dapat disimpulkan bahwa intervensi MBSR pada pasien DM memiliki hubungan dengan peningkatan peredaran glukosa, yang mana HA1c berkurang.

Spiritual mindfulness merupakan terapi yang mengadopsi teori keperawatan adptasi callista Roy, dimana berfokus pada psikologis dengan pemberian nafas disertai pemberian motivasi yang dsisipi dengan kalimat-kalimat dzikir, sehingga kesadaran dan penerimaan akan kondisinya. Model konsep dan teori Roy menekankan pada aspek fisik dan psikis sehingga terbentuk perilaku adaptif.

Selama pasien melakukan mindfulness based on benson relaxation akan diperdengarkan rekaman suara yang berisikan kalimat-kalimat motivasi, kesyukuran dan kesabaran yang akan menstimulasi prefrontal cortex kemudian menghasilkan perubahan perspektif diri yang berbentuk kesadaran untuk mengambil hikmah terhadap kondisi yan dialami saat ini dan akan meningkatkan toleransi terhadap stres dan menurunkan ketegangan otot, selanjutnya akan mengubah respon kognitif dan emosional spiritual individu sehingg adapat mempengaruhi suasanan hati menjadi rileks mempertahankan emosi yang positif yaitu penerimaan diri dan peningkatan keyakinan. Sehingga kadar gula darah berkurang. Berdasarkan data dan hsil penelitian yang telah dijabarkan maka dapat disimpulkan bahwa penderita DM mengalami perunahan fisik yang akan berdampak pada perubahan psikologis sehingga tidak terkontrolnya kadar gu adalam darah.

Penatalaksanaan yang dapat dilakukan perawat sebagai salah satu intervensi keperawatan adalah dengan memberikan latihan spiritual mindfulness based on benson relaxation. Intervensi mindfulness merupakan bagian dari keperawatan holistik, karena meningkatkan kesadaran atas keadaan yang terjadi saat ini dengan pemusatan pikiran dan perhatian kepada keyakinan tanpa pemberian reaksi penolakan yang dapat menurunkan gejala psikis dan fisik. Tujuan dari 
penelitian ini adalah untuk mengetahui pengaruh dari intervensi spiritual mindfulness based on benson relaxation terhadap kecemasan dan kadar gula pasien DM tipe 2 yang menggunakan jenis penelitian quasi- experimental dengan rancangan pre test - post test control group design.

\section{METODE}

Penelitian ini menggunakan penelitian QuasyExperiment dengan pendekatan pre post test control group design dengan intervensi terapi spiritual mindfulness based on benson relaxation. Rancangan ini menggunakan kelompok kontrol (pembanding) yang memungkinkan peneliti melihat perubahan kecemasan dan kadar gula darah penderita DM tipe 2 sebelum dan sesudah diberikan terapi terapi spiritual mindfulness based on benson relaxation. Teknik pengambilan sampel dalam penelitian ini dilakukan dengan teknik non probability samping jenis consecutive sampling dimana semua subjek memenuhi kriteria inklusi dan eksklusi selama penelitian berlangsung. Kriteria inklusi: Penderita DM tipe 2 dengan kadar gula darah acak $>144 \mathrm{mg} / \mathrm{dl}$ atau kadar gula darah puasa $>126 \mathrm{mg} / \mathrm{dl}$, penderita DM tipe 2 yang berusia 40 - 65 tahun, kondisi sadar, kooperatif dan mampu berkomunikasi dengan lancar, pasien mengalami kecemasan (ringan dan sedang), beragama islam, dan bisa membaca, menulis dan mendengar. Kriteria eksklusi: Penderita mengalami komplikasi kronik DM (gagal jantng, gagal ginjal, anemia), sedang menjalani teapi komplementer lain dan atau mengalami gangguan intelektual dan gangguan kognitif.

Instrumen yang digunakan dalam penelitian ini adalah kuesioner SRAS Zung untuk kecemasan dan glukometer untuk mengukur GDP dan GDPP. Analisis uji validitas dan reliabilitas menggunakan program pearson product moment dengan $r$ tabel $=0,444(\mathrm{~N}=20$, level of significance $=0,05)$. Hasil uji validitas kusioner kecemasan adalah 3 item pertanyaan tidak valid, yaitu pertanyaan nomor $4 \quad(\mathrm{r}=0,419)$, pertanyaan nomor 14 $(\mathrm{r}=0,336)$, dan pertanyaan nomor $16(\mathrm{r}=0,419)$. Hasil uji reliabilitas kuesioner ini adalah $r$ alpha cronbach's 0,945 . Karena hasil $r$ hitung lebih besar dari $r$ tabel, maka kuesioner ini reliabel atau konsisten. Penelitian ini dilakukan di Rs. Islam A. Yani Surabaya pada bulan April. Penelitian dilakukan stelah mendapatkan persetujuan dari Komite Etik Penelitian Universitas Nahdlatul Ulama Surabaya dengan nomor 181/EC/KEPK/UNUSA/2020
Pedoman Pelaksanaan Spiritual mindfulness based on benson relaxation: Dilakukan pertemuan dengan responden kelompok intervensi untuk melaksanakan terapi spiritual mindfulness based on benson relaxation yang dilakukan dengan mendemonstrasikan langkah-langkah peaksanaan intervensi yang sesuai dengan SOP menggunakan media mp3 yaitu media berisi rekaman suara peneliti dalam format mp3 berisi panduan mindfulness based on benson relaxation yang dapat didengarkan melalui headset.

Responden diminta untuk mengatur posisi senyaman mungkin, boleh sambil memejamkan mata atau meluruskan pandangan kemudian pasien diminta untuk membawa perasaan dan pikiran pada fisik Dri ujung rambut sampai ujung kaki. Langkah selanjutnya pasien diminta mulai memusatkan perhatian pada pernafasan disertai dengan dzikir (mengucapkan kalimat "Astaghfirullahal'adzim") kemudian mulai melepaskan ketegangan pikiran, rasa cemas dan khawatir yang berlebihan. Seluruh prosedur latihan dilakukan selama 15 menit tiap kali latihan sebanyak sehari sekali, yaitu pagi hari sebelum memulai aktivitas. Intervensi dilakukan selama 4 minggu. Pelaksanaan selanjutnya dilakukan secara mandiri di rumah masing-masing dan dikunjungi secara door to door yaitu dengan melakukan observasi pada pelaksanaan terapi yang dilakukan pasien dan pengukuran GDA dilakukan setelah intervensi terakhir diminggu keempat. Sedangkan kelompok kontrol hanya mendapatkan standart prolanis dan tidak diberikan intervensi spirital mindfulness based on benson relaxation selama proses berlangsung, tetapi diberikan setelah pelaksanaan pengukuran akhir.

\section{HASIL}

Penelitian yang dilakukan peneliti meliputi karakteristuk responden dan pengaruh intervensi terhadap kecemasan dan kadar gula. Hasil yang sudah didapatkan selama penelitian dilakukan uji statistik. Karakeristik umum responden berdasrakan data demografi yang disajikan terdiri dari usia, jenis kelamin, tingkat pendidikan, pekerjaan, dan lama menderita DM disajikan pada tabel 1. 
Tabel 1.

Karakteristik responden pada kelompok kontrol dan kelompok perlakuan

\begin{tabular}{|c|c|c|c|c|}
\hline \multirow{2}{*}{ Karakteristik } & \multicolumn{2}{|c|}{ Kelompok Kontrol $(n=30)$} & \multicolumn{2}{|c|}{ Kelompok Perlakuan $(n=30)$} \\
\hline & $\mathrm{f}$ & $\%$ & $\mathrm{f}$ & $\%$ \\
\hline \multicolumn{5}{|l|}{ Umur (tahun) } \\
\hline $46-55$ & 18 & 60 & 13 & 43,3 \\
\hline $56-65$ & 12 & 40 & 17 & 56,7 \\
\hline $66-75$ & 0 & 0 & 0 & 0 \\
\hline \multicolumn{5}{|l|}{ Jenis Kelamin } \\
\hline Laki-laki & 11 & 36,7 & 11 & 36,7 \\
\hline Perempuan & 19 & 63,3 & 19 & 63,3 \\
\hline \multicolumn{5}{|c|}{ Pendidikan Terakhir } \\
\hline SD & 12 & 40 & 11 & 36,7 \\
\hline SMP & 8 & 26,7 & 11 & 36,7 \\
\hline SMA & 9 & 30 & 5 & 16,7 \\
\hline $\mathrm{D} 3 / \mathrm{S} 1 / \mathrm{S} 2$ & 1 & 3,3 & 3 & 10 \\
\hline \multicolumn{5}{|l|}{ Pekerjaan } \\
\hline PNS & 3 & 10 & 3 & 10 \\
\hline Swasta & 5 & 16,7 & 7 & 23,3 \\
\hline Wiraswasta & 13 & 43,3 & 9 & 30 \\
\hline Pensiunan & 5 & 16,7 & 5 & 16,7 \\
\hline Tidak Bekerja & 4 & 13,3 & 6 & 20 \\
\hline \multicolumn{5}{|l|}{ Lama DM } \\
\hline $1-3$ tahun & 13 & 43,3 & 11 & 36,7 \\
\hline 4-6 tahun & 10 & 33,3 & 10 & 33,3 \\
\hline$>6$ tahun & 7 & 23,3 & 9 & 30 \\
\hline
\end{tabular}

Tabel 1 menunjukkan distribusi responden sebagian besar lulusan SD dengan pekerjaan berdasarkan karakteristik. Sebanyak 60 responden penderita DM tipe 2 sebagian besar berusia 46 65 tahun, responden perempuan lebih banyak dari pada laki-laki, dengan tingkat pendidikan terbanyak wiraswasta dan lama menderita DM 1 3 tahun.

Tabel 2.

Spiritual mindfulness based on benson relaxation terhadap tingkat kecemasan

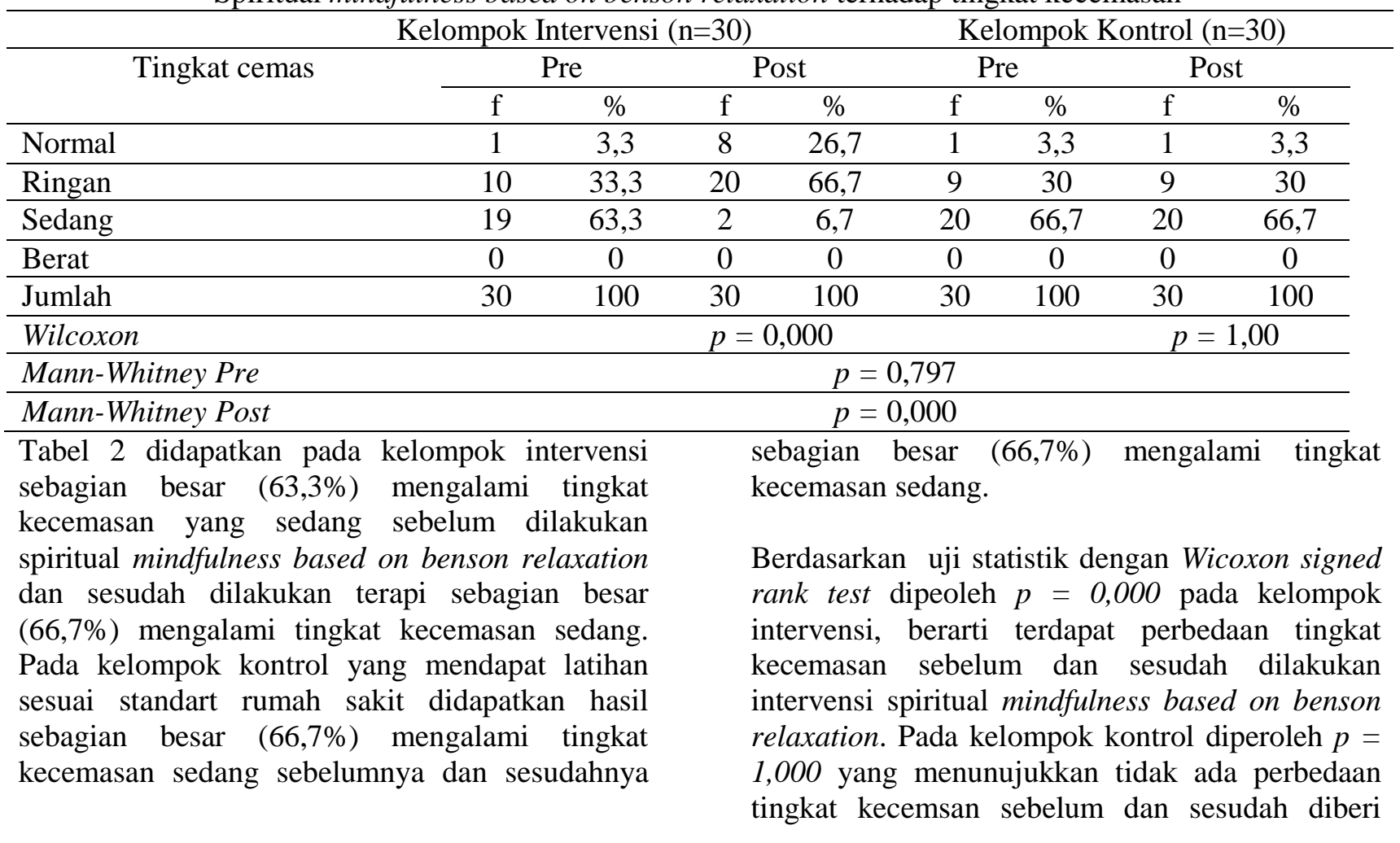


terapi. Pada uji statistik dengan Mann-Whitney pre test diperoleh $p=0,797>\alpha 0,05$, yang artinya tidak ada perbedaan tingkat kecemasan antara kelompok intervensi dan kelompok kontrol. Pada uji statistik dengan Mann-Whitney post test diperoleh $p=0,00>\alpha 0,05$, berrati $\mathrm{H}_{0}$ ditolak yang artinya terdapat perbedaan tingkat kecemasan antara kelompok intervensi dan kelompok kontrol. Jadi ada pengaruh spiritual mindfulness based on benson relaxation terhadap tingkat kecemasan.

Tabel 3.

Spiritual mindfulness based on benson relaxation terhadap kadar gula

\begin{tabular}{|c|c|c|c|c|c|c|c|c|}
\hline \multirow{3}{*}{ Kadar gula } & \multicolumn{4}{|c|}{ Kelompok Intervensi $(n=30)$} & \multicolumn{4}{|c|}{ Kelompok Kontrol $(\mathrm{n}=30)$} \\
\hline & \multicolumn{2}{|c|}{ Pre } & \multicolumn{2}{|c|}{ Post } & \multicolumn{2}{|c|}{ Pre } & \multicolumn{2}{|c|}{ Post } \\
\hline & $\mathrm{f}$ & $\%$ & $\mathrm{f}$ & $\%$ & $\mathrm{f}$ & $\%$ & $\mathrm{f}$ & $\%$ \\
\hline$<80$ & 0 & 0 & 11 & 36,7 & 0 & 0 & 1 & 3,3 \\
\hline $81-159$ & 5 & 16,7 & 19 & 63,3 & 3 & 10 & 3 & 10 \\
\hline$>160$ & 25 & 83,3 & 0 & 0 & 27 & 90 & 26 & 86,7 \\
\hline Wilcoxon & \multicolumn{3}{|c|}{$p=0,000$} & & \multicolumn{2}{|c|}{$p=0,48$} & & \\
\hline Mann-Whitney Pre & \multicolumn{8}{|c|}{$p=0,451$} \\
\hline Mann-Whitney Post & & & & $p=0$ & & & & \\
\hline
\end{tabular}

Tabel 3 didapatkan pada kelompok intervensi sebagian besar hampir seluruhnya memiliki kadar gula $>160(83,3 \%)$ sebelum dilakukan spiritual mindfulness based on benson relaxation dan sesudah dilakukan terapi sebagian kecil $(63,3 \%)$ memiliki kadar gula 81 - 159. Pada kelompok kontrol yang mendapat latihan sesuai standart rumah sakit didapatkan hampir seluruhnya (90\%) memiliki kadar gula >160 sebelumnya dan sesudahnya hampir seluruhnya $(86,7 \%)$ memiliki kadar gula $>160$.

Berdasarkan uji statistik dengan Wicoxon signed rank test dipeoleh $p=0,000$ pada kelompok intervensi, berarti terdapat perbedaan kadar gula sebelum dan sesudah dilakukan intervensi spiritual mindfulness based on benson relaxation. Pada kelompok kontrol diperoleh $p=0,48$ yang menunujukkan tidak ada perbedaan kadar gula sebelum dan sesudah diberi terapi. Pada uji statistik dengan Mann-Whitney pre test diperoleh $p=0,451>\alpha 0,05$, yang artinya tidak ada perbedaan kadar gula antara kelompok intervensi dan kelompok kontrol. Pada uji statistik dengan Mann-Whitney post test diperoleh $p=0,00>\alpha$ 0,05 , berrati $\mathrm{H}_{0}$ ditolak yang artinya terdapat perbedaan kadar gula antara kelompok intervensi dan kelompok kontrol. Jadi ada pengaruh spiritual mindfulness based on benson relaxation terhadap kadar gula.

\section{PEMBAHASAN}

Pengaruh Spiritual Mindfulness based on Benson Relaxation terhadap Kecemasan

Hasil penelitian menunjukkan adanya pengaruh signifikan dari pemberian intervensi spiritual mindfulness based on benson relaxation terhadap kecemasan pasien DM tipe 2 pada kelompok intervensi. kelompok intervensi didapatkan sebagian besar $(63,3 \%)$ mengalami tingkat kecemasan yang sedang sebelum dilakukan spiritual mindfulness based on benson relaxation dan sesudah dilakukan terapi sebagian besar $(66,7 \%)$ mengalami tingkat kecemasan sedang. Uji statistik dengan Wicoxon signed rank test dipeoleh $p=0,000$ pada kelompok intervensi

Hasil penelitian ini selaras dengan penelitian lainnya yang menunjukkan bahwa mindfulness berpengaruh terhadap kecemasan. Penlitian yang dilakukan oleh Miichaela, et al (2017) menyelidiki efek neurologis terapi mindfulness, yang dapat disimpulkan bahwa mindfulness berpengaruh terhadap gejala stress. Rosenszweig (2007) menyatakan perubahan kontrol glikemik, berat badan, tekanan darah, dan gejala psikologis - stres pada pasien DM tipe 1 dengan memberikan intervensi MBSR yang dilaksanakan selama 4 minggu. Sedangkan Anselm, et al (2016) menyatakan bahwa memfokuskan pernafasan saat mindfulness efektif dalam pengaturan regulasi emosi, penurunan aktivasi anigdala da meningkatkan integrasi prefrontal.

Mindfulness merupakan suatu keadaan dimana seseorang menerima keadaan yang terjadi saat ini. Latihan mindfulness based on benson relaxation merupakan bagian dari Mindfulness Based Stress Reduction (MBSR) yang merupakan teknik dasar untuk seseorang mencapai keadaan sadar atas keberadaannya. Dalam latihan nafas yang fokus dan diiringi kalimat dzikir, individu akan diarahkan untuk merasakan sensasi pernafasan. Pemberian terapi mindfulness menyebabkan 
peningkatan relaksasi dan kenyaman dengan menekankan stressor stres dan cemas.

Dalen (2014) menyebutkan mindfulness meditation lebih menfokuskan pada pemusatan perhatian dalam mengatasi masalah kognitif dan mengalihkan pikiran untuk menurunkan stress emosional. Mindfulness based on benson relaxation meupakan terapi yang efektif dalam menangani masalah psikolois, karena terapi ini berfokuskan pada pemusatan perhatian yang terjadi saat ini. Dalam proses mindfulness terjadi beberapa peristiwa yang saling berpengaruh, seperti experince being present (pengalaman), yang mana dari pengalamn sesorang dapat dijadikan pelajaran. Mindfulness dalam proses ini diartikan kemampuan seseorang dalam memusatkan perhatian terhadap apa yang terjadi saat ini berdasarkan pengalaman yang telah terjadi sebelumnya dengan mempertahankan kesadran, penerimaan dan perhtain setiap saat. Kesadaran (awareness) kemampuan seseorang untuk mengendalikan pengalaman yang muncul kembali dengan cara yang sehat. Penerimaan (acceptence) menrima apa yang terjadi tanpa adanya denial dan menolak. Perhatian (attention) memusatkan perhatian pada apa yang terjadi. Proses transformasi, melalui mindfulness didapatkan akses ke batin secara langsung untuk wawasan, transformasi dan penyembuhan (White, 2014).

Intervensi ini menggunakan pendekatan teori keperawatan Callista Roy yaitu kemampuan mekanisme koping dan control procces individu akan disesuaikan dengan tingkat adaptasi individu tersebut, yang dapat diobservasi melalui adaptasi fisiologi yakni kemampuan fisik individu merespon stimulus, adaptasi konsep diri, kemampuan psikologis (perasaan) dan spiritual (kepercayaan akan Tuhan).

Intervensi spiritual mindfulness based on benson relaxation dapat membuat seseorang sadar akan kondisinya saat ini tanpa menyalahkan orang lain dan lingkungan, dengan mendekatkan diri kepada Tuhan dengan keyakinan apapun yang terjadi adalah pemberian Tuhan dengan pemberian motivasi dengan mendengarkan rekaman suara yang berisikan istruksi untuk memfokuskan pikiran dengan tarik nafas yang diirngi dengan kalimat dzikir yang dilakukan selama 15 menit pada tiap pelaksanaan yang dilakukan sehari sekali sebelum memulai aktivitas. Doa dari sudut pandang ilmu kesehatan mental merupakan terapi psikiatrik, setingkat lebih tinggi daripada psikoterapi biasa. Hal ini dikarenakan zikir dan doa mengandung unsur spiritual keruahanian, keagamaan, yang dapat membangkitkan harapan dan percaya diri pada diri klien atau penderita, yang pada giliranya kekebalan tubuh dan kekuatan psikis meningkat sehingga mempercepat proses penyembuhan (Hawari,2009).

Intervensi ini dapat menghambat aktivitas saraf simpatik yang mengakibatkan penurunan terhadap konsumsi oksigen oleh tubuh dan selanjutnya otot-otot tubuh menjadi relaks sehingga menimbulkan perasaan tenang dan nyaman. Perasaan rileks akan diteruskan ke hipotalamus untuk menghasilkan Corticotropin Releasing Factor (CRF) dan Corticotropin Releasing Factor (CRF) mengaktifkan anterior pituitary untuk mensekresi enkephalin dan endorphin yang berperan sebagai neotransmiter yang mempengaruhi suasana hati menjadi rileks dan senang. Di samping itu, anterior pituitary sekresi Adrenocorticotropic hormone (ACTH) menurun, kemudian Adrenocorticotropic hormone (ACTH) mengontrol adrenal cortex untuk mengendalikan sekresi kortisol. Menurunnya kadar Adrenocorticotropic hormone (ACTH ) dan kortisol menyebabkan cemas, stres dan ketegangan menurun yang akhirnya dapat menurunkan tingkat depresi.

\section{Pengaruh Spiritual Mindfulness Based on Benson Relaxation terhadap Kadar Gula}

Penelitian ini menunjukkan bahwa intervensi spiritual mindfulness based on benson relaxation berpengaruh terhadap kadar gula darah pada pasien DM tipe 2. Pada kelompok intervensi didapatkan sebagian besar hampir seluruhnya memiliki kadar gula >160 (83,3\%) sebelum dilakukan spiritual mindfulness based on benson relaxation dan sesudah dilakukan terapi sebagian kecil $(63,3 \%)$ memiliki kadar gula 81 - 159. Uji statistik dengan Wicoxon signed rank test dipeoleh $p=0,000$ pada kelompok intervensi.

Penelitian ini sejalan dengan penelitian lian yang menunjukkan bahwa mindfulness berpengaruhn terhadap kadar gula darah. Tuti (2018) menyatakan bahwa intervensi spiritual mindfulness based on breathing pada pasien DM kadar gula turun, kecemasan menurun dan tekanan darah stabil. Rosenzweig., et al (2007) menyatakan bahwa stres dapat menyebabkan peningkatan produksi kortisol, noreipnefrin, beta endorfin, glukagon dan hormon pertumbuhan, meningkatkan kadar glukosa darah dan resistensi insulin. Melalui praktik mindfulness yang terdiri dari beberapa teknik, yaitu body scan, mindful breathing, mindful walking, mindful eating, dan 
mindful communication dimana pada semua praktik latihan ini, peserta berlatih untuk memberi perhatian penuh pada pengalaman saat ini, tidak berespon negatif dan reaktif terhadap kejadian, pikiran, emosi, atau sensasi eksternal yang muncul dinilai sangat efektif dalam mengurangi respon stres psikologis individu yang selanjutnya juga dapat memperbaiki regulasi gula darah individu.

Intervensi ini dapat menekan rasa tegang sehingga timbul perasaan rileks. Perasaan rileks akan diteruskan ke hipotalamus untuk menghasilkan Corticotropin Releasing Hormone (CRH) dan Corticotropin Releasing Hormone (CRH) mengaktifkan anteriorpituitary untuk mensekresi enkephalin dan endorphin yang berperan sebagai neotransmiter yang mempengaruhi suasana hati menjadi rileks dan senang. Di samping itu, anterior pituitary sekresi Adrenocorticotropic hormone (ACTH) menurun, kemudian Adrenocorticotropic hormone (ACTH) mengontrol adrenal cortex untuk mengendalikan sekresi kortisol. Menurunnya kadar Adrenocorticotropic hormone (ACTH) dan kortisol menyebabkan stres dan ketegangan menurun yang akhirnya dapat menurunkan tingkat kecemasan, stress dan depresi (Sholeh, 2006).

Kecemasan bisa memicu aktivasi saraf simpatik yang dapat menyebabkan terjadinya takikardia, peningkatan frekuensi pernapasan, tekanan darah meningkat, dan penyempitan saluran napas, dan menyebabkan kelelahan (Thomas, 2003; Wong, et al., 2001). Stres yang berkepanjangan menyebabkan aktivitas aksis HPA yang meningkat sehingga kadar kortisol meningkat yang diiringi oleh peningkatan glukosa di sirkulasi. Kortisol juga mempengaruhi fungsi insulin terkait dalam hal sensitivitas, produksi dan reseptor, sehingga glukosa darah tidak bisa diseimbangkan (Putra, 2011).

Hasil penelitian menunjukkan bahwa ada perbedaan bermakna pemberian terapi spiritual mindfulness based on benson relaxation terhadap kadar gula rata-rata bersadarkan pengukuran antar waktu pada yang artinya terdapat perbedaan pengaruh yang besar dari pemberian intervensi tiap minggu terhadap penurunan kadar glukosa darah rata-rata pasien DM tipe 2.

\section{SIMPULAN}

Terdapat pengaruh spiritual mindfulness based on benson relaxation terhadap kadar gula darah sebelum dan sesudah diberi intervensi. Spiritual mindfulness based on benson relaxation juga berpengatuh terhadap kadar gula darah sebelum dan sesudah diberi intervensi.

\section{DAFTAR PUSTAKA}

Alawiyah, Tuty. (2018). Pengaruh Spiritual mindfulness Based on breathing Exercise Terhadap Kecemasan, Kadar Gula Darah dan Tekanan Darah Pasien Diabetes Melitus Tipe2. Tesis. Universitas Airlangga Surabaya. Surabaya.

Anselm, Doll., Hölzel, B.K., Bratec, SM., Boucard, CCXie, X. (2016). Mindful attention to breath regulates emotions via increased amygdala-prefrontal cortex connectivity. J. NeuroImage: Elsevier 134 (2016)

305-313. http://dx.doi.org/10.1016/j.neuroimage.201 $\underline{6.03 .041}$

Benson, H \& Proctor, W. (2000). Dasar-dasar respons relaksasi. Bandung: Kaifa.

Brantley Jeffrey., Wendy Millstine. (2011). True Belonging: Mndful Practices to Help You Overcome Loneliness, Connect with Other, and Cultivate Happiness. New York: New Harbinger Publications https://www.goodreads.com/book/show/11 325933-true-belonging

Dalen, J., Smith, BW., Shelley, BM., Sloan, AL, Leahigh, L., Begay, D. (2010). Pilot study: Mindful Eating and Living (MEAL): Weight, eating behavior, and psychological outcomes associated with a mindfulnessbased intervention for people with obesity. Complementary Therapies in Medicine 1 5, http://doi:10.1016/j.ctim.2010.09.008

Gautam, Y., Sharma, A.K., Bhatnagar, M.K., \& Trehan, R.R. (2009). A Cross Sectional Study of QoL of Diabetic Patient at Tertiary Care Hospital in Delhi. Indian Journal of Community Medecine, 34 (4), 346-350 diakses 25 Januarri 2020 dari https://dx.doi.org/10.4103\%2F0970$\underline{0218.58397}$

Greenstein, B., Wood, D.F. (2010). At e Glance: Sistem Endokrin Edisi kedua. Jakarta: Erlangga 
Hawari D., (2001). Manajemen stres, cemas, dan depresi. Jakarta : Fakultas Kedokteran Universitas Indonesia.

Hayes, S., Walts, T. (2010). Acceptance and Commitment Therapy: In Cognitive Behavioral Therapy in Clinical Practice. New York: The Guilford Press https://doi.org/10.1111/j.14682850.2008.00137.x

International Diabetes Federation. (2010). Diabetes Atlas, Fifth Edition diakses 21 Januarri 2020 dari http://www.idf.org/diabetesatlas/5e/theglobal-burden

Nursalam. (2013). Metodologi Penelitian Ilmu Keperawatan: Pendekatan Praktis. Edisi 3.Jakarta:Salemba Medika

PERKENI. (2015). Konsensus Pengelolaan dan Pencegahan DM Tipe 2 di Indonesia.Jakarta: PB Perkeni

Perry, A.G., \& Potter, P.A. (2005). Buku ajar fundamental keperawatan: Konsep, prosesdan praktik. (Ed 4). (Y. Asih, Terj.). Jakarta: EGC

Reynolds, R.M., Strachan, M.W.J., Labad, J., Lee, A.J., Frier, B.M., Fowkes, F.G., Mitchell,R., Secki, J.R., Deary, I.A., Walker, B.R., Price, J.F. (2010). Monitoring Cortisol Levels andCognitive Ability in People with Type 2 Diabetes. Diabetes Care, Volume 33, No 4, April2010 diakses Januari 2020 dari https://doi.org/10.2337/dc09-1796

Rosenzweig S. (2007). Mindfulness Based stres reduction is associated with improved glycemic control in type 2 diabetes mellitus: a pilot study. Diakses pada 25 Januari $2020 \quad$ http://www.alternativetherapies.com/at/web_pdfs/rosenzweig.pdf

Sofiana Loly Irma, Elita Veny, dan Utomo Wasisto. (2012). Hubungan Antara Stress Dengan Konsep Diri Pada Penderita Diabetes Mellitus Tipe 2. Jurnal Ners Indonesia, Vol.2, No. 2, Maret 2012350 diakses Januarri $2020 \quad$ dari http://dx.doi.org/10.31258/jni.2.2.167-176

Tovote K Annika., Flessr j., Snippe E., Peeters C.T.M., Emmelkamp P.M.G., Sanderman
R.M Scahoevers J., (2014). Individual mindulness-based cognitive therapy and cognitive behavior therapy for treating depressive symptomps in patient with diabetes: result of randomized controlled trial. Diabetes Care, 37: 2427-2434 https://doi.org/10.2337/dc13-2918

Tyas, M.D.C. (2008). Hubungan Perawatan Diri akan Persepsi Sakit dengan Kualitas Hidup Pasien DM Tipe 2 dalam Konteks Keperawatan di Kota Blitar. Tesis. UniversitasAirlangga Surabaya. Surabaya.

West, A. M. (2008). Mindfulness and well-being in adolescence: An exploration of four mindfulness measures with an adolescent sample. Dissertation Abstracts International: Section B. Sciences and Engineering, $\quad 69(05), \quad 3283$. https://psycnet.apa.org/record/2008-99220$\underline{242}$

White L., (2014). Mindfulness ini nursing: an evolutionary concept analysis. Journal of Advanced Nursing 70 (2), 282-294 https://doi.org/10.1111/jan.12182 